\title{
Reassessing the ESP Course Offering to Engineering Students: Identifying Correspondences between the Course Contents and Workplace Language Needs (Case Study of Students of College of Engineering at Majmaah University, K.S.A)
}

\author{
Dr.Ishraga Bashir \\ English Department, Faculty of Arts \\ Al-Neelain University, Khartoum, Sudan.
}

Dr.Ehab Fouad

English language Department, Preparatory Program Al- Majmaah University, Kingdom of Saudi Arabia.

\begin{abstract}
English is needed and is used extensively in the field of engineering and work. One more important point is that Graduates from Saudi Universities are likely to face difficulties coping with communication in positions in which the working language is English. This is not only because the amount of time and their exposure to English are insufficient, but also because the courses offered do not prepare them adequately for the job market. This research presents the steps for conceiving an acceptable curriculum that would enable identifying specific workplaces in which the language of communication is English. It is widely recognized that a high percentage of today's school leavers find themselves unemployed due to lack of relevant skills and qualifications and low educational attainment.
\end{abstract}

\section{INTRODUCTION}

The ever-changing nature of English teaching has been influenced by some factors such as the educational requirements and career objectives. These factors resulted in different views and cogent approaches to language teaching. Training competent learners is considered as one of the most important goals that all these approaches try to achieve. In order to fulfill different needs of different groups of learners, some modifications were made in the teaching of English, which in turn led to the development of teaching English for Specific Purposes (ESP), "an international movement characterized by a concern with adult students' roles as English language speakers and writers outside of the classroom, and by its grounding in pedagogy" (Johns \& Dudley-Evans, 1991). In this regard, Widdowson (1983) cites Palmer's crucial statement on the importance of relating language teaching to the particular needs of learners: "We cannot design a language course until we know the linguistic and career needs of the students for whom the course is intended, as any program of study depends on the needs of the students. (p. 14)". The present study tries to integrate the subjects such as communication at workplace, ESP, and Engineering together. Specifically speaking, the present study tries to evaluate the effectiveness of the ESP course offered to the students of engineering inxxx in increasing their English language proficiency and communication at workplace. 


\section{RESEARCH PROBLEM}

There is a gap between English taught in schools and the workplace.

The English taught to Engineering students in Saudi Arabia is not enough to prepare students for the workplace.

\section{LITERATURE REVIEW}

Instructional programs for English for Specific Purposes (ESP) have become popular recently, mainly due to the growing need to use English internationally in the fields of science, technology, trade, commerce, administration, diplomacy, and law. Learners are seeking proficiency in the English language in specific domains of use to serve their specific purposes.

The most widely obvious explanation for this increasing demand for ESP has been made by Hutchinson and Waters (1987), who note that this trend is closely related to the developments in economy, technology, linguistics, and educational psychology in the last fifty years. Today, in many parts of the world, many business and educational institutions offer ESP courses to help learners function effectively in their academic studies and professions. According to Amirian \& Tavakoli (2009), "ESP is viewed as a cover term for teaching and learning English for multiple specific purposes: EAP, EOP and others" (p. 3). In the past 35 years, it has received increasing attention and has developed to become one of the most significant areas of TEFL today. Its development is reflected in the increasing number of universities offering an MA in ESP (e.g. The University of Birmingham, and Aston University in the UK) and in the number of ESP courses offered to overseas students in English speaking countries (Anthony, 1997). Hutchinson \& Waters (1987) propose two prominent ESP levels of evaluation: learner assessment and course evaluation. These two forms of evaluation, they maintain, are not always distinct. In other words, evaluation of the learners reflects not only the learners' performance but also to some extent the effectiveness or otherwise of the course. In ESP, there are three basic types of learner assessment: placement tests, achievement tests and proficiency tests; and according to Alderson \& Waters (as cited in Hutchinson \& Waters, 1987) there are four main aspects of ESP course evaluation to be considered: a) what should be evaluated? b) How can ESP courses be evaluated? c) Who should be involved in the evaluation? d) When (and how often) should evaluation take place? In many universities in Turkey, the demand for English courses that are designed to meet the specific needs of the students in their academic studies is increasing and writing is reported to be the skill that is mostly needed, therefore, designing courses that meet the specific needs of the learners is of great importance. A learning-centered approach (Nunan, 1996) to course design advocates the involvement of learners in contributing to the design of lessons, materials, and the course. Studies have, however, shown that there can be discrepancies among the opinions of learners, instructors, and professionals in relation to what learners need. The concept of needs assessment is considered as the backbone for ESP instructional design. McDonough (1984) suggests that the learner should be at the heart of any teaching program. Thus, information on his/her language needs contributes to drawing up a profile to establish coherent objectives and to taking subsequent decisions on course content. Nevertheless, she proposes that this assumption built on learner-centeredness as a principle can be adopted in all teaching situations. According to Hutchinson and Waters (1987), it is always possible to specify the needs of learners; but what distinguishes between ESP and General English is not the existence of a need but rather the awareness of the need. They further explain this awareness of the target situation-a definable need to communicate in English- distinguishes the ESP learner from the general English learner. 
In Munby's (1978) Communication Needs Processor (CNP), needs analysis is considered as a systematic and important stage in course design. Munby (1978) introduces eight variables in a dynamic relationship that should be considered in needs analysis. These variables involve information about the participant, purposive domain, setting, interaction, instrumentality, dialect, target level, communicative event, and communicative key. Besides the data collected in standard needs analysis studies, information such as psychological settings, different environments in which the language will be used; the role-set, the people with whom the participant will interact, the nature and size of participation; and the attitudinal tones or keys, how the target communicative acts are performed are also essential in deciding the language content and the learning context in any CNP. In their learning-centered approach, Hutchinson and Waters (1987) view needs analysis as a stage of ESP instructional design which should involve two aspects: target situation analysis and learning needs analysis. Their view is quite similar to Munby's CNP in terms of the questions that should be asked during the needs analysis process about the identity and purpose of the learner, the place and time of the study, the people the learner will interact with, or the level of the proficiency required. However, Hutchinson and Waters make the distinction between target needs and learning needs clearer by developing two separate frameworks for each involving different sets of questions. Robinson (1991) also argues that learners' present learning needs and target situation needs should be considered with equal weight and simultaneously in syllabus design. With the increasing significance of needs analysis in ESP, studies on models and approaches to needs assessment have also gained importance. Several systematic and thorough procedural models of needs assessment give direction to instructional design studies in the field of education. Smith and Ragan (1992), Dick and Carey (1996), Posner and Rudnisky (1997) have established instructional design models in which the needs assessment procedures for school and nonschool learning environments are described. One of the most detailed and systematic models for needs assessment are proposed by Kemp, Morrison and Ross (1994). The significance of this model is that the needs assessment is not considered as a simple pre-instructional activity but considered as a research project that involves all the basic stages of a research study.Various course design studies have shown that there are considerable discrepancies in opinions of groups that are involved in needs analysis studies. Yin (1988), in a study comparing course content and language learning activities in different ESP courses, concludes that despite the agreement among employers on the types of tasks that are demanded in the work context, there are important differences in the skills that are required by these tasks. Similarly, the results of a needs assessment study carried out by Jenkins et al (1993) reflects significant discrepancies between the needs reported by the ESP instructors and the content course instructors. In this study, while the ESP instructors did not view report writing as an important skill for their engineering students, students were expected to write reports as a requirement of most departmental course they took during their undergraduate study.Studies also demonstrate that instructors' and learners' perceptions of needs do not always match. Similarly, Spratt (1999), in a study that compares learners' preferred activities with teachers' perceptions of what those preferences were, concludes that the instructors could perceive their students' preferences with only 50\% accuracy. There is, however, evidence that students have definite opinions about their abilities in various skills, and can assess the importance of sub-skills to in their academic studies. Generally, in the needs assessment studies in ESP the data obtained from two sources of data, such as the students themselves and their instructors of English are compared. In the present study, however, the data obtained from five sources, the students, the instructors of English, departmental instructors, employers and the written productions of the students, are compared. The present study seeks answer to the following research question: 
To what extent does the syllabus of the engineering fulfil the workplace needs?

\section{METHODOLOGY}

The Subjects of this study has been chosen purposeful, the selection based on one criterion, and that all the subjects are graduates of Al-Majmaah University in order to have an idea about the number of graduates joining companies. The researcher has chosen two major companies in Riyadh area; SABEC and ARAMCO, the other sources are Materials from Majmaah University from where the subjects graduate. The number of the respondents are: 57 HR Managers, 204 employees, and 470 Engineering Students.

To sum up, the sample for this investigation consisted of two companies representing a number of different employees and engineers. Participants were Saudi nationals working at ARAMCO and SABEC, students of college of engineering and college of sciences and computer technology.

Questionnaire has been designed to find out the following: The needs of the workplace if the syllabus of the engineering fulfils the workplace needs. How the gap between English for Academic purposes and occupational purposes can be bridged.

\section{The Stake holders:}

- Engineering Students studying in Engineering Branch in KSA

- HR Office / HR Manager in KSA

- Employee in Engineering Domain in KS

\section{Insufficient ESL Competencies for ESP Course}

\section{RESULTS \&DISCUSSION}

Mere $29.8 \%$ of students have agreed that their competence in ESL is enough for taking any ESP course. Remaining 33\% of the students have competence to some extent and majority $37.2 \%$ believe their level of competence is not enough for an ESP course which indicate towards bringing overall changes in the entire academic system from top to bottom.

\section{Lack of Experience in using English in Professional Work Environment}

None agreed to have fully relevant experience in using English in work environment. 62.8\% agreed to some extent that could be probably due to their occasional involvement in professional interactions during training, internship or outside college environment. However, 37.2 replied having no such experience which shows that they were perhaps never been put in any professional work environment or did not have chance to work in any industrial live project or internship involving their interaction in English. This hints towards training students for work place situation by creating artificial workplace like environment and teaching work-place communicative tasks.

\section{Lacking use of ESP books as reference}

None of the students answered that he would always be referring or reading to ESP related books. 33\% said they referred to some extent or on some occasions. Whereas, majority $67 \%$ did not read any ESP related book. This shows that either they are not referred good ESP books or are not having access to them or not motivated or competent enough to read them. 


\section{Scope of Coordinating ESP related Ideas / publication}

None of the students claimed to be sharing or publishing online or offline anything about ESP and around $84 \%$ of them agreed to some extent. $16 \%$ of them never shared or published anything online or offline, formally or informally.

However, effort should be to know what these $84 \%$ if students share or publish related to ESP. Their views must be brought to common platform to understand their level of understanding or problems in ESP studies.

\section{Use of internet resources for improving ESP skills}

$67 \%$ of students are using internet based resources in ESP and try to apply knowledge and skills to improve their communication standard in work place situations. This is positive outcome. $17 \%$ of them are using internet based resources to some extent. Around $16 \%$ of them are not using any such internet resources for any such reasons. This hints towards organizing and recommending the right resources online for better and improved results.

\section{Scope for improvisation in alignment of ESP policy and Organizational Needs}

$13.8 \%$ of students believe that ESP policy at college/university is in line with organizational needs. However, remaining $33 \%$ agree to some extent only and majority $53.2 \%$ are not happy saying it is not in line with organizational needs. This hint towards coordinating the ESP policy to align with the organizational ESP needs.

\section{Lack of coordination in past ESP curriculum and ESP policy}

$84 \%$ of students agreed that past ESP curriculum being in line with nation's ESP policy. However, none of them agreed being it in line fully. $16 \%$ were unhappy revealing that curriculum did not remain in line with the ESP policy. Their unhappiness hint towards bringing things in coordination and to find out what wrong they find in the ESP education system.

\section{Scope for more Classes from Visiting Faculty from Industry}

13.8 of students said they had classes from guest faculty or they assumed that their existing faculty having industrial experience. $16 \%$ of students agreed that they had certain classes or to some extent. Majority of them, making it $70.2 \%$ revealed that they had no classes from guest faculty from industry. This hint towards need for more classes from industry professionals or teaching content directly from work place to make them adapt to work place situation much before they start their job.

\section{Scope for syllabus alignment with national curriculum standard}

Mere $13.8 \%$ of students agreed that their past ESP syllabus was in line with nation's ESP curriculum standard. Whereas remaining, making it $86.2 \%$ of them revealed that past ESP syllabus was not in line with nation's ESP curriculum standard. This hints towards lack of coordination in aligning syllabus with national curriculum standard.

\section{Lacking Comprehensive Evaluation of the ESP Program in line with approved course objectives}

Mere $13.8 \%$ of students agreed that evaluation of the ESP program was in line with approved course objectives. Whereas remaining, making it $86.2 \%$ of them revealed that it was in line with approved course objectives to certain extent. This hints towards lack of coordination between ESP course objectives and ESP program. 


\section{Lack of awareness about role of ESP Stake holders}

All of the students are not familiar with the role ESP stake holders play in the society in shaping the future of ESP in the country. 33\% of students agreed to some extent. Whereas remaining, making it $62.8 \%$ of them show that they are not familiar with the exact role of all stake holders in society. This hints towards lack of information on students' side and need to bring more awareness.

\section{FINAL REMARKS}

When choosing or being assigned an ESP textbook, teachers need to assess its usefulness. The steps to make teaching methods correspond with employment needs require gathering data from stakeholders through observation, interviews, and questionnaires to describe the specific workplace language context. This data can then be used to evaluate the textbook and will lead to valid decisions for supplementing the textbook with extra material or activities. Using the textbook as the sole instructional guide, from cover to cover, without any supplemental material, will not address the realities of individual learning situations. By getting to know the real needs of learners and their potential employers, ESP teachers can judge the distance between classroom material and the requirements of the workplace and be able to bridge that gap.

\section{References}

Arabian Cultural Mission in the U.S.A. (1991). Education in Saudi Arabia (1st ed).

Brumfit, C.J. \& Johnson, K. (1989).The Communicative Approach to Language Teaching.Oxford University Press.

Dudley-Evans, Tony (1998). Developments in English for Specific Purposes: A multi-disciplinary approach. Cambridge University Press.ed.). Oxford ; New York: Published for and on behalf of the Council by Pergamon Press.

Edwards, P. (1996). Action research on creative/verbatim task production. In: J.Pique, J. VicentAndreu- Beso, D.J. Viera (eds) (1996). English in Specific Settings. Valencia: Universidad de Valencia, pp. 175-179.

Ellis, M. \& Johnson, C. (1996). Teaching Business English.Oxford Handbooks for Language Teachers.Oxford University Press.

Graddol, D., Leith, D., \& Swann, J. (1996). English : History, diversity, and change. Milton

Graves, K. (1996). Teachers as course developers. England: Cambridge University Press, 1996.

Hall, J. K. (2001). Methods for teaching foreign languages : Creating a community of learners in the classroom. Upper Saddle River, N.J.: Merrill Prentice Hall.

Halliday, M. A. K. (1973). Explorations in the functions of language. London,: Edward Arnold.

Harding, K (2007) English for Specific Purposes, Oxford University Press

Harrison, R. (1996). The training of ESP teachers in Russia. English for Specific Purposes - Russia, 2: 24-26.

Hutchinson, T. \& Waters, A. (1987). English for Specific Purposes.A Learning-centred Approach. Cambridge, Cambridge University Press.

Johns, Ann M. \& Dudley-Evans, Tony (1991). English for Specific Purposes: International in Scope, Specific in Purpose. TESOL Quarterly 25:2, 297-314.

Johns, Ann M. \& Dudley-Evans, Tony (1991). English for Specific Purposes: International in Scope, Specific in Purpose. TESOL Quarterly 25:2, 297-314.

Jones, G. (1990). ESP textbooks: Do they really exist? English for Specific Purposes, 9, 89-93.

Jones, G. (1990). ESP textbooks: Do they really exist? English for Specific Purposes, 9, 89-93.

Kennedy, C. \& Bolitho, R. (1984). English for Specific Purposes.McMillan Publishers.

Keynes England, London ; New York: Open University; Routledge. 
Krashen, S. (1985). The Input Hypothesis: issues and applications. N.Y.: Longman.

Mackay, R., \& Palmer, J. (Eds.) (1981). Languages for Specific Purposes: Program design and evaluation. London: Newbury House.

Mackay, R., \&Mountford, A. (Eds.). (1978). English for Specific Purposes: A case study approach. London: Longman.

McDonough, J. (1984). ESP in perspective: A practical guide. London: Collins ELT. meeting the needs of second language learners. Oxford: Oxford University Press.

Munby, J. (1978) Communicative Syllabus Design. Cambridge: Cambridge University Press. 